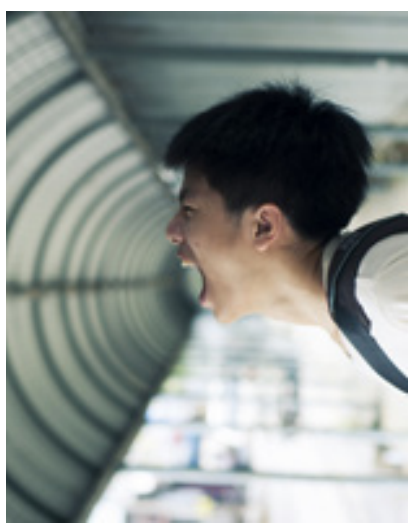

'Sound Waves'.

PC: William Chew.
State surveillance is undoubtedly one of the central barriers to open and active political engagement among many students from the People's Republic of China (PRC).

\section{Can Chinese Students Abroad Speak? Asserting Political Agency amid Australian National Anxiety}

\section{Shan WINDSCRIPT}

ustralian nationalist discourse rarely acknowledges the existence of Chinese international students except within ethnicised stereotypes-variously, as 'cash cows', 'CCP spies', and 'patriotic students brainwashed from birth' (Four Corners 2019; Hamilton 2018, 4). Daphne Zhao-a pseudonymous Australian-based Chinese graduate student-offers a welcome break from this increasingly paranoid oversimplification in her recent op-ed in this issue of the Made in China Journal. Albeit with its own limitations, her article attempts to complicate the prevailing narrative of a singular 'Chinese diaspora' toeing the official Party line. Yet Zhao, who speaks through personal experience of engaging with mainland students about the ongoing Hong Kong protests, elaborates a narrative of victimhood. In her account, overseas Chinese students who hold dissenting views inevitably retreat into a 'compelled reticence' in the face of growing Chinese nationalism and an oppressive surveillance state.

State surveillance is undoubtedly one of the central barriers to open and active political engagement among many students from the People's Republic of China (PRC). And Zhao is certainly not alone in feeling concerned about the current environment (Kwai 2019). But representing overseas mainland students as passive victims of the omnipresent power of the Chinese Communist Party (CCP) offers neither a solution for overcoming this dilemma, nor does it sufficiently capture the actual diversity of political opinion among the students. If anything, it also has the potential to reinforce Australian racial anxieties and CCP authoritarianism, both of which remain committed to removing the political agency of the Chinese students by collapsing the Communist Party-state and the people' into a homogenous whole.

In this response to Zhao, I propose an alternative frame of thinking, one that puts political agency at the foreground as not only desirable but necessary, and one that centres voices of dissent-however fragmentary-among Chinese international students. Although I ground my comments here in an Australian 
This racial stereotyping

of PRC students is

both a product of, and

a contributor to, the

current hypersensitivity

about the CCP's

influence on Australian

democracy and

sovereignty. context, I hope this piece offers a contribution to a wider discussion among progressives worldwide about engaging and building radical solidarities with students from China.

In Australia-a country whose settler-nationalism is historically rooted in white supremacist race-thinking, compounded with a recently-resuscitated Cold War paranoiastudents from the PRC stereotypically figure in public commentary as disruptive to Australian cultural norms and values (Laurenceson 2018). Mainstream discourse draws attention to mainland students as at best incapable of, and at worst hostile to, democratic participation. Since 2016, in the face of a rising and globally more assertive China, there has been growing suspicion that Chinese students are likely to be 'agents of the CCP' who threaten the intellectual freedom of Australian academics (Laurenceson 2018, 40). In media coverage on the recent pro-Hong Kong rallies held across Australia, focus is placed on the tensions and 'unbreachable' differences between supporters of Hong Kong democracy on the one hand, and aggressive, ultra-nationalist PRC students on the other. Coinciding with this, Chinese students have been criticised for their lack of English proficiency, and blamed for lowering Australian higher education standards (Laurie 2019).

This racial stereotyping of PRC students is both a product of, and a contributor to, the current hypersensitivity about the CCP's influence on Australian democracy and sovereignty. Promoted in recent years by the major political parties, think tanks, and public figures, fears about Beijing infiltrating Australian democratic institutions have pushed the country's moral panic over Chinese migrants and students to the point of hysteria. Clive Hamilton's 2018 book, Silent Invasion: China's Influence in Australia, played a notable role in fuelling this fearmongering campaign (Brophy 2018). The outburst of concerns over the national loyalty of Gladys Liu-a Member of the Parliament from the Liberal Party, originally from British Hong Kong-is the most recent expression of Australia's anti-Chinese sentiment. Pundits like Clive Hamilton, having previously shown no concern over Liu's homophobic and transphobic politics, have wasted no time in denouncing her alleged connection with the CCP (Hamilton 2019). According to Hamilton, no ethnic Chinese can be trusted politically unless they prove their loyalty to Australia (Tarabay 2019).

The racialised anxiety has manifested itself in ugly forms in a spate of recent events targeting mainland students across the country. In mid-September 2019, Monash University's student union decided to ban all international students from running 
in elections so as to prevent a 'takeover' of the union by PRC students (Sakkal 2019). In late July, an 'anti-Chinese influence' rally was called by a group of Australian students at the University of Queensland (UQ), fanning the racist flames in the name of protecting Australian national interests against UQ's Confucius Institute (Power 2019). The rally provoked calls for the deportation of patriotic mainland students, and for an 'antiChinese riot'-a direct reference to the violent demonstrations against Chinese miners on the goldfields of nineteenth-century Australia (Hioe 2019).

But mainstream peddlers of this anxiety continued to agitate. Instead of condemning the increasingly obvious racist discourse, Clive Hamilton lampooned UQ's Vice-chancellor Peter Høj as the CCP's 'best academic friend' for supporting the Confucius Institute (Hamilton 2019, Twitter post). Underpinning his reasoning was not evidence, but a sanctimonious, toxic, malicious delirium widely shared among conservative and right-wing circles: Australian democracy is vulnerable to contamination by the 'covert, coercive or corrupting' behaviour of Xi Jinping's Communist China (Turnbull 2017).

What really lies at the heart of all this talk about mainland Chinese influence is a deep-seated, anxious Australian nationalism that ossifies ethnic communities to fulfil its 'White nation fantasy' of racial dominance (Hage 2000). This fantasy treats Aboriginal and non-white people as what Ghassan Hage $(2000,18)$ terms 'merely national objects to be moved or removed according to a White national will'. This Australian nationalism is unwilling to, and incapable of, grasping the diverse cultural universes of diasporic communities-a diversity that runs directly against ethno-nationalist racial imagination. This Australian nationalism, in casting mainland students as a homogenous, 'brainwashed' mass of CCP agents who are incapable of thinking critically beyond the Party line, erases the capacity of the students to act as full political beings.

The ruling authorities of mainland China chase their own fantasies of social and ideological homogeneity.
The ruling authorities of mainland China chase their own fantasies of social and ideological homogeneity. Their efforts to control information through censorship, propaganda, and their ongoing 'patriotic education campaign'-implemented originally by Deng Xiaoping in the early 1990s-reflect their desire to integrate 'the people', especially the youth, into the Party-state as loyal and ideologically committed citizens. To this end, the Chinese government, like its Australian counterpart, also denies Chinese people the capacity and possibility of genuine political engagement. 
While the CCP likes to boast about the patriotism of its overseas students, we should not draw the conclusion that what they want is what they get. As Melbourne academic Fran Martin (2018) says: 'It is true to say that the patriotic education campaign has had an effect on young Chinese ... [but] students are smart people, they are educated, they are not cultural dopes ... no-one is so stupid as to be simply taking on a government line and never questioning that.'

In September 2019, I talked to a number of mainland international students about the Hong Kong protests. These students were engaged and chatty, if not always well-informed. Unsurprisingly, some of them were nationalistic, some of them politically unsophisticated. But all of them were curious and open-minded about what was going on in Hong Kong, andwith reasonable precautions-perfectly capable of expressing themselves and partaking in discussions and debates.

Solidarity from these Chinese students with the Hong Kong protesters is common, and an overall aspiration for fair and critical judgement informs their evaluations. One student, for example, expressed both his frustrations with the CCP's control over the media, and his support for the Hong Kong protesters:

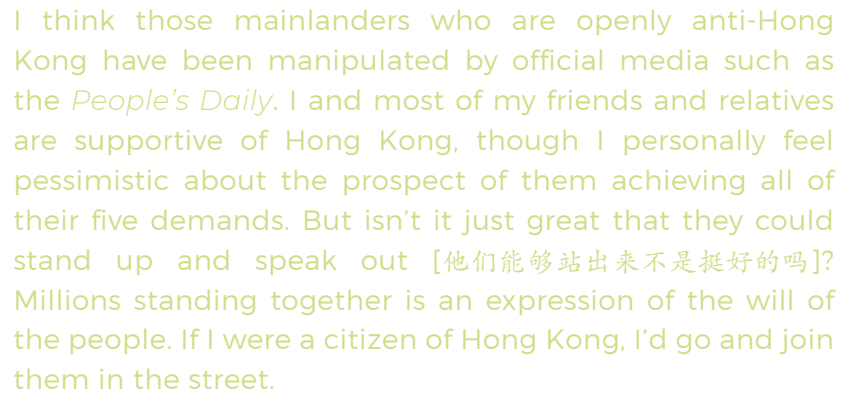

Another mainlander who came to study in Australia over a year ago expressed similar feelings of solidarity for Hong Kong and criticism toward the Chinese propaganda state:

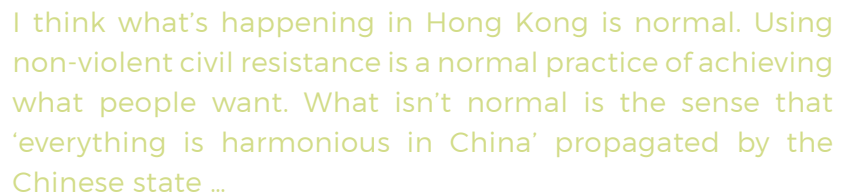


None of the students I spoke to was oblivious to the risk of speaking out against the Chinese Party-state. But none of them expressed exceptional concern over CCP surveillance either. 'We are not influential figures. We are just ordinary, unimportant little people [to the state], one student said with a chuckle.

Another student spoke against the tendency to exaggerate fears over the CCP:

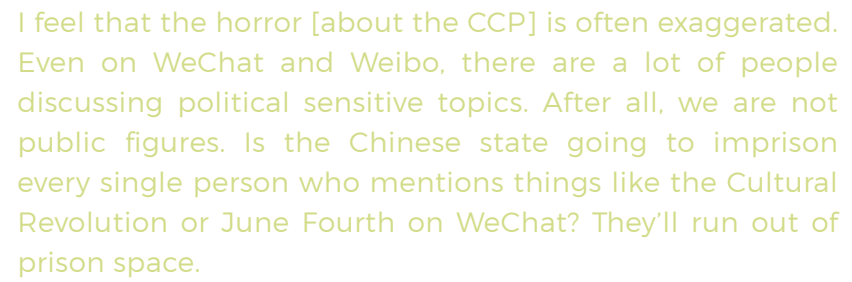

Last year, I wrote an essay [in Australia] arguing that Mao

Zedong was a mass murderer. My argument at the time was probably too simplistic, but I didn't feel scared at all

for writing it. China may be an authoritarian regime, but it's far from being able to make everyone believe two plus two equals five.

I am not suggesting that we dismiss Chinese students' concern about CCP surveillance. But exaggerating the reach of state power, and self-censorship for fear of retribution, only serves to generate more fear and further the alienation of Chinese students, foreclosing the possibility for social and political change. The only way to overcome this impasse is for international students to assert themselves as political actors and to build solidarity with progressive forces and struggles in Australia and across the world. Individual expressions of dissent against power are unlikely to be effective. Taking part in collective movements for social transformation, on the other hand, would be empowering, uplifting, and can achieve greater impact.

Students from the PRC can, and have been, expressing critical opinions on topics considered sensitive by the Chinese Partystate. But their voices are often silenced or drowned out by the 
Instead of dismissing

these students' politics

or questioning their

ability to think critically,

we need to inspire

confidence among

them to be more

politically active. oversimplified 'spectacles' of Chinese students undermining Australian values and norms favoured by the news media to attract public interest within a climate of white Australian nationalism. To let the diverse voices of Chinese students be heard, we first need to be vigilant of, and actively oppose, stereotypical representations of the students in mainstream discourse, and to shift our focus to positive examples of political engagement among the mainland students.

More broadly, we need to develop productive ways to engage with students from the PRC on political questions. What divides people is not their ethnic-national affiliation but their politics. Instead of dismissing these students' politics or questioning their ability to think critically, we need to inspire confidence among them to be more politically active. Creating a supportive and inclusive environment, listening to and building trust with them, taking their opinions and perspectives seriously with a constructive attitude, and having healthy dialogues and debates with them are some of the ways in which we could achieve this goal. In other words, we should engage with mainland students in the same way we would engage with other people politically.

The success of a recent meeting of Chinese and Hong Kong students at the University of Sydney offers a case in point. Organised by mainland students, the meeting was pitched cautiously with the aim of fostering 'mutual and rational' talks with Hongkongers. It attracted some 50 to 60 attendees, with a good contingent of students from Hong Kong. And the students took precautions to protect their privacy. The meeting heard presentations in Mandarin Chinese, with English translations projected on the screen, followed by a bilingual Q\&A. Mainland students articulated their various thoughts and positions on the Hong Kong cause: criticisms, reservations, justifications, and support. And the meeting did not descend into a shouting match. As David Brophy, a Sydney academic who attended the event as a guest speaker, reports: 'After two hours people still wanted to hang around and keep talking-there's clearly enthusiasm and interest for events like this. The organizers emphasized the importance of upholding free speech on campus, and collected post-its for a Lennon Wall at the end' (Facebook post, 13 September 2019).

Perhaps more importantly than anything else, we need to organise and build radical internationalist solidarity with mainland Chinese students beyond the recognition of 'nations' as the natural foundation of identity and belonging. Like migrant and refugee workers everywhere, international students are vulnerable to discrimination, exploitation, and abuse. We 
should ally ourselves with them for a shared commitment to fighting inequality and systemic oppression. Unions and progressive grassroots organisations have the power to drive the realisation of this vision. The newly-formed Migrant Workers' Centre in Melbourne has led the way in realising such multi-ethnic alliances 'from below' (MWC 2018).

In early May 2019, a group of casual academics and members of the National Tertiary and Education Union (NTEU) at the University of Melbourne issued an open letter condemning the racist portrayal of Asian international students in the Four Corners's documentary, Cash Cows (Open Letter 2019). The documentary, ostensibly concerned with the well-being of foreign students-most from China and India-present them as scapegoats for the problems caused by Australia's increasingly corporatised and casualised neoliberal university system. Asian international students are portrayed as undesirable 'back-door' migrants, incompetent with basic academic tasks, and ill-suited for Australian life and values. Perpetuating a long historical tradition of racial exclusion by language competence, Cash Cows masquerades its call for regulating borders as investigative journalism.

Within 48 hours of the show's airing, the open letter from the NTEU's casual unionists gathered more than 160 signatories from academics across the country. Soon after that, at the NTEU rally against casualisation, held outside Melbourne University's Chancellery, over 70 protesters stood in solidarity with international students against the airing of Cash Cows. The crowd cheered and applauded as an international student activist spoke up against discrimination and university exploitation (Fela 2019).

There can be no oxygen for the exclusionary logics of nationalism within our common struggles for global justice that transcend the bounds of ethnicity and nationality. We should recognise that, despite our different passports, our aspirations for freedom from oppression have no borders.

*I thank the students for sharing their stories and thoughts with me; and Jimmy Yan, David Brophy, Max Kaiser, and the editors of the Made in China Journal for reading this piece in draft forms and providing helpful comments and suggestions. 